\title{
MIR223 Gene
}

National Cancer Institute

\section{Source}

National Cancer Institute. MIR223 Gene. NCI Thesaurus. Code C80727.

This gene is involved in the regulation of gene expression and plays a role in the development of hepatocellular and ovarian carcinomas, acute promyelocytic leukemia and chronic myeloid leukemia. 